\title{
Climate change and economic approaches into water allocation: optimization via direct benefits of water-the case study of Rudbar Lorestan hydropower dam (Iran)
}

\author{
Masoud Kazem ${ }^{1} \cdot$ Daryl Mc.Phee ${ }^{1} \cdot$ Alireza Torkaman Rashid $^{2} \cdot$ Amir Kazem $^{3}$
}

Received: 7 June 2015/Accepted: 7 September 2016/Published online: 23 September 2016

(C) Springer International Publishing Switzerland 2016

\begin{abstract}
Climate change will affect hydrologic patterns in the Middle East over future decades. Already limited water resources will become further limited, creating further challenges for water allocation protocols. While there is no integrated climate/water allocation framework to develop sophisticated dynamic allocation patterns, determining the economic value of water in various markets is one way to optimize water allocation. In this paper, a non-linear optimizer code through the Conjugate Gradient Method has been applied to optimize water allocation in the Rudbar Lorestan Hydropower system (Iran) across four sectors (agriculture, industry, power, and urban). Climate scenarios and direct benefits of water in each sector have been considered as the inputs of the model for a 37 years period (2014-2050). The results of optimized allocation show that while each particular sector is impacted substantially from different climate scenarios, the total direct benefits of water
\end{abstract}

Masoud Kazem

Masoud.kazem@student.bond.edu.au;

Mas_kazem@yahoo.com

Daryl Mc.Phee

dmcphee@bond.edu.au

Alireza Torkaman Rashid

Torkaman_al@civileng.iust.ac.ir

Amir Kazem

kazem_amir@gsme.sharif.edu

1 Faculty of Society and Design, Bond University, Gold Coast 4229, Australia

2 Department of Civil Engineering, Iran University of Science and Technology, Narmak, 16846-13114 Tehran, Iran

3 Graduate School of Management and Economics, Sharif University of Technology, Azadi Ave, 11365-11155 Tehran, Iran in the basin vary between the narrow ranges of $14.75-16.75$ billion USD for the same period. By considering the major characteristics of flexibility and adjustability, this methodology (Optimization via Economic Value of Water) can be considered an adaptive approach for addressing climate change and water allocation challenges.

Keywords Climate change - Water allocation .

Optimization $\cdot$ Economic value of water $\cdot$ Adaptation

\section{Introduction}

Globally, there are competing human uses for finite freshwater resources. While some water reservoirs may be designed and used for a single purpose, many are multipurpose which includes being used for agriculture, hydropower, and urban water supply. There is a need to "optimally" allocate finite water resources among competing users, and this can be a complex task. The allocation of water among competing uses is and will continue to be a critical area of research and an area that affects the livelihoods and well-being of millions of people. As well as allocation between human uses, it is also increasingly recognized that freshwater should be allocated to the environment to ensure the functioning of downstream aquatic ecosystems, including downstream fisheries production that supports livelihoods and provides food. In comparison with single-purpose reservoirs, the optimization procedure for multi-purpose reservoirs serving various demands like agriculture, hydropower, and urban is complex. The challenge for optimal allocation of water resources is that the values between different stakeholders are not homogenous. In particular when considering the needs of hydropower, an additional level of complexity 
arises. Arunkumar and Jothiprakash (2012) believe that this complexity arises from the fact that hydropower production is not an isolated incident. Thus, more sophisticated algorithms are needed to comprehend non-linear and complex behaviors of system.

An additional challenge in water allocation is climate change. Climate change is projected to substantially alter the distribution, volume and timing of rainfall, and, hence, water resources across the globe. There is a need to factor climate change into water allocation and allocation mechanisms, particularly in locations where rainfall is projected to be substantially reduced, and where human populations are large and growing. Water allocations have typically focused on mechanisms for allocations to and between agricultural sectors that incorporate economic factors and long-term inflow data (and uncertainty) (McKinney 1999; Young and Loomis 2014). There is increasing realization that water allocations need to focus on more than just agricultural sectors, and expand to other sectors, and there are examples where this has been done, for example, in the Maipo river basin in Chile (Rosegrant et al. 2000). Water allocations have frequently focused on the Cost-Benefit Analysis (CBA), however, determining the true "value" of water is challenging. Considering all aspects of water cost needs a wide study over socio-economic, political, and environmental issues, and this is particularly the case when the allocation arrangements need to consider more than one sector. George et al. (2011) offered an integrated economic modeling framework to evaluate water allocation which contains the Cost-Benefit Analysis. Cost-Benefit Analysis would be an effective method for allocation if all model inputs were known completely and did not alter over time, but this is rarely if ever the case.

Undoubtedly, the agriculture sector is the predominant water consumer in Iran (Safa et al. 2012). However, the price of water allocated to this sector has been reduced via the governmental subsides gained by oil marketing resources (Ansari et al. 2014; Jaghdani et al. 2012). The value of water in non-agricultural uses is typically at double the maximum agricultural value, and of course, the value of water for human consumption in times of extreme shortage is effectively infinite. This leads analysts to believe that there is scope for enormous increase in economic benefit by market-based transfers of water from lowvalue agricultural use to high- value new uses in other sectors (Perry 2001). This fact could be mentioned as one of the driving factors of projects, such as the Dez to Qomrood water transfer project.

Hydrological model selection in hydroclimatic studies has been always a controversial subject, because of different sensitivities to the threshold values and also different uncertainties of parameters amongst the current models (Jin et al. 2010; Demirel et al. 2013). However, recent research indicates that uncertainty from hydrologic model selection is considerably smaller than that inherent in climate models (Global Circulation Models) (e.g., Jiang et al. 2007; Najafi et al. 2011; Exbrayat et al. 2014). Jiang et al. (2007) compared and quantified the capability of the six water balance models in simulating the climate change effects at basin scale. The results of the comparison identified that all six models have similar capabilities in terms of reproducing historical water balance components. The big difference between the models' results arose from soil moisture modeling. By eliminating the direct index of soil moisture in the modeling procedure, the variability between the models and, hence, the importance of any one model over another are reduced with little or no impact on the output at least in the monthly scale.

Considering that the climatic factors are the main source of uncertainties, at least in these types of long-term predictions, a lumped rainfall runoff model based on a genetic programming code could be used to develop future runoff series from historical data. The scientific literature extensively discusses the significant differences in results from the global circulation models (GCM) in climatic scenarios forecasting. To address the significant differences, the use of multi-model projection is well established (e.g. Andersson et al. 2006; Serrat-Capdevila et al. 2007; Van

Table 1 Global Circulation Models applied in Rubar Lorestan basin to forecast flow pattern till 2050

\begin{tabular}{|c|c|c|}
\hline Applied GCM & GCMs with similar results in basin scale & Forecasted domain and behavior \\
\hline GFDLCM-2.0 & CNRM-CM3, CSIRO-30, GFDLCM-2.0 & Very optimistic: runoff raises in the basin scale \\
\hline GISS-EH & $\begin{array}{l}\text { ECHO-G, GISS-EH, INMCM-30, MICRO-HI, MRI-232A, } \\
\text { UKHADCM3, MPI-ECH5 }\end{array}$ & Optimistic: runoff declines in the basin scale $(0-10 \%)$ \\
\hline UKHADGEM & $\begin{array}{l}\text { BCCRBCM2, CCCMA-31, CCSM-30, UKHADGEM, MICRO- } \\
\text { CMED,NCARPCM1 }\end{array}$ & Moderate: runoff declines in the basin scale (10-20\%) \\
\hline GFDLCM-2.1 & GFDLCM-2.1 & $\begin{array}{l}\text { Pessimistic: runoff declines in the basin scale } \\
(20-30 \%)\end{array}$ \\
\hline FGOALS-1G & FGOALS-1G, IPSL-CM4 & $\begin{array}{l}\text { Very pessimistic: runoff declines in the basin scale } \\
\text { (more than } 30 \% \text { ) }\end{array}$ \\
\hline
\end{tabular}

The behavior of each model and similar GCMs are illustrated too 
Fig. 1 Geographical location of Rudbar Lorestan proposed hydropower dam

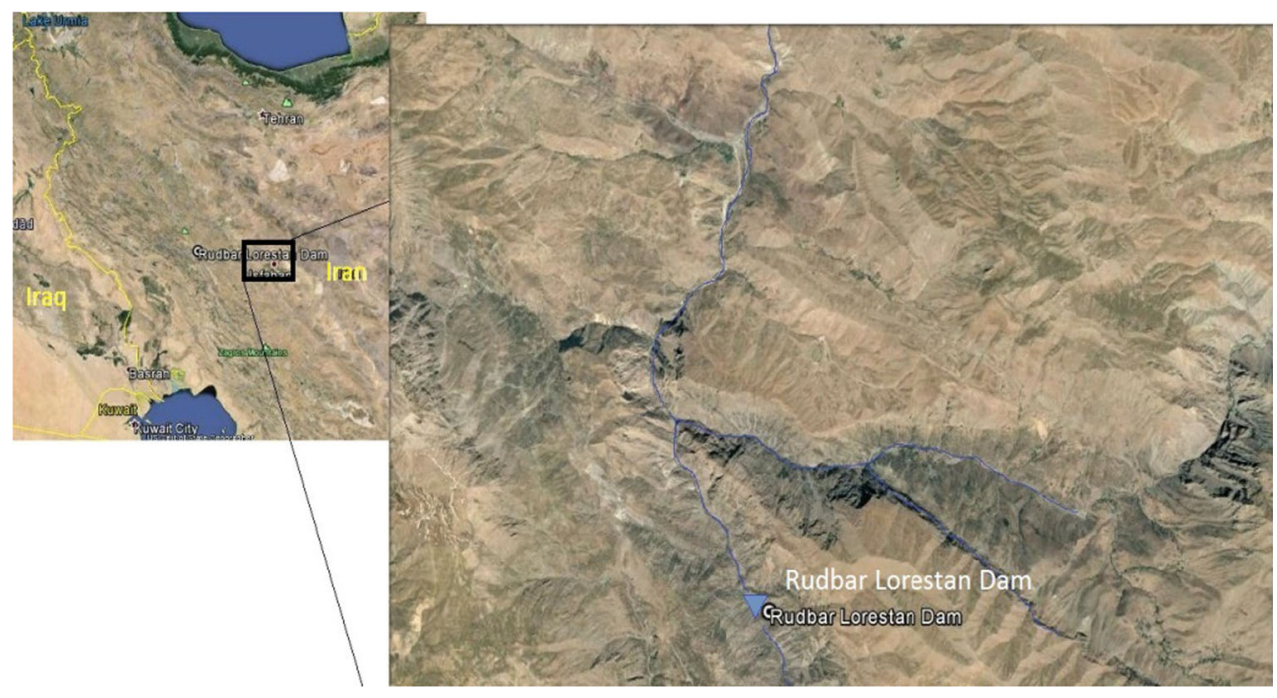

Oldenborgh et al. 2012; Chikamoto et al. 2013). In this paper, the results of five GCMs are selected and downscaled to apply into modeling procedure. The outputs from the five GCMs chosen represent the full suite of predictions from upper to lower extreme predictions. The utilized GCMs and their forecasted scenarios are shown in Table 1. A water balance model has been used to simulate inflows and demand points for the proposed Rudbar Lorestan Dam. Gleick (1987) identified that the water balance model can provide considerably more information on the regional hydrologic effects of climatic changes that is currently available. Figure 1 illustrates the schematic model of a single reservoir with local inflows and demand points at the upper hand which is used for the case study (Rudbar Lorestan) of this paper. Rudbar Lorestan is a proposed gravity concrete hydroelectric dam with designed height of $158 \mathrm{~m}$ and the storage capacity of $200 \mathrm{MCM}$ (Million Cubic Meter) located in the Zagros mountain range in Iran (Fig. 1). The proposed $450 \mathrm{MW}$ hydropower planet will supply both local and national electric network during the peak hours. The reservoir is located in the major basin of the great Dez which flows into great Karun, the most important and biggest river of Iran. The great Dez basin has been the subject of several major water transfer projects since the $1980 \mathrm{~s}$ and the proposed Rudbar Lorestan dam is also located under the distribution facilities of a water transfer project supplying urban and industrial demands of Qom City.

\section{Methodology}

Integrated optimization-allocation models that allow the assessment of the effects of alternative water management strategies have been advocated for and used previously. For example, Schlüter et al. (2005) suggested these tools for long-term decision-making. Similar to the case study of this paper, Schlüter et al. used a water allocation module in accordance with the historical data in a semi-arid basin. A multi-disciplinary approach is required to inform water allocations and to ensure that such allocations are optimized. The use of such optimization approaches is relatively recent and the process is more complex when the number of stakeholders increases. Here, the direct benefit approach is used. This method has been recognized by the Food and Agriculture Organization of the United Nations (FAO) as a reliable technique, applied in comprehensive research, e.g., Turner (2004), by considering long-term climate scenarios to maximize total economic benefits of Rudbar Lorestan basin and to minimize uncertainty. Hydroeconomic modeling has been a topical and evolving research subject, since computer-aided analysis developed in the water resources management area. Heinz et al. (2007) considered the implications and applications of hydroeconomic models as river management tools for the European water framework. In that study, relevant economic parameters, such as cost recovery and water pricing, were discussed. In another notable work, the impacts of global change have been considered in the hydroeconomic modeling for the Spain Gállego river basin (Graveline et al. 2014). Hydroeconomic modeling and analysis have been also a topical issue in Iran, especially where maintaining or enhancing agricultural productivity and cost recovery are essential factors in decision-making; for example, in the case of cultivation of rice at Guilan province (Kalashami et al. 2014) and also for drinking water (Pour and Kalashami 2012).

The applied model used in this paper includes climate scenario, hydrology, policy (allocation protocol), economic, and basin blocks. In the climate scenario block, to 
evaluate future hydroclimatic condition, the $0.5 \times 0.5 \mathrm{de}-$ gree resolution map of basin was adjusted by GCMs introduced in Table 1. Reverse distance methodology and historical data were applied to downscale the results. Consequently, a lumped GP-based rainfall-runoff has been used to forecast runoff scenarios in the hydrology block. The five GCMs selected ranged in results from very optimistic to very pessimistic scenarios. In the economic block, a matrix of water price is defined, in which the applied price for each specific demand (during the forecasted period) is drawn from consideration of current data and inflation rate. The forecasted runoff was then applied in the optimizing code under constrains of water balance and a series of operational limits. The optimization block intends to find the best allocation pattern maximizing the total economic benefit index in this block, the matrix of prices is multiplied by various water allocation matrixes to produce an index showing the total economic benefits during the forecasted period. Therefore, the target is to find a water allocation matrix that maximizes the total economic benefit index. Owing the fact that the basin is located in mountain region with steep slopes and rocky ground, the effect of ground water has not been considered in this model, as it was deemed to not be a parameter in this case that would not substantially influence the model outcomes. The flowchart of the methodology is illustrated in Fig. 2.

In the basin/land block, the reliability of water supply for the urban sector assumed to be $95 \%$ and the minimum allocation set to $7 \mathrm{MCM} /$ Month (70 \% of average monthly demand). The $450 \mathrm{MW}$ power plant limited to $35 \%$ annual busy time and the Francis turbines' efficiency assumed to be $95 \%$. The initial storage was set to $114 \mathrm{MCM}$. By considering $20 \mathrm{MCM} /$ Year demand in the industrial sector, the minimum allocation set to $1 \mathrm{MCM} / \mathrm{Month}$. As a rational assumption, the agriculture sector is able to carry higher risk than either the urban and industry sectors; therefore, the minimum monthly allocation is set to two MCM/Month, while the annual demand in this sector is around $100 \mathrm{MCM}$ (Hydrologic assumptions and materials are available at "Appendix 1"). By the defined constraints, the conjugate gradient-based optimizer model was run to find the $\mathrm{A}^{*}$ allocation matrix producing the maximum value of TEco index. According to the design data, the urban demand of Qom city would be supplied by a water transfer link. To develop a tangible factor, water allocation from the deviation point into Qom city has been assumed as the decision parameter.

The core of the optimization block has been developed on the base of the Conjugate Gradient Method in LINGO optimization code. The implication of LINGO codes was based on relatively early computer-aided water management studies as like as optimized allocation for pollution control (Brown et al. 1999) and continued to new research applications like comprehensive simulation of water management (Singh and Panda 2013). Conjugate gradient method is a modification of the Steepest Descent Method which avoids the zigzagging effect of the latter which can reduce the iterations that let the user to monitor the calculation procedure more efficiently. However, the trade-off is that each iteration takes computationally longer. The non-linear behavior of model emerged from the two main factors; Hydroelectric power production equation and the Volume-Depth relation of the reservoir (Fig. 3). The goal of optimization is to find optimum water allocation time series for each consumer sector (here in this paper: agriculture, industry, and urban at the upstream of reservoir, and hydropower produced by varying volumes of downstream release). For this purpose, developing allocation matrix is a very useful method to both understanding of procedure and applying in optimizing codes. There are notable cases of matrix methodology in recent researches; solving water allocation problem in the Spree River basin by Messner et al. (2006), and optimization of Nebhana Reservoir Water Allocation by Alaya et al. (2003) are very good samples of this methodology for developing multicriteria decision support systems. According to the most predominant definition, the matrix format of each probable time series combination can be shown as matrix " $A$ " defined below:

$A=\left[\begin{array}{ccc}a_{11} & \cdots & a_{1 n} \\ \vdots & \ddots & \vdots \\ a_{m 1} & \cdots & a_{m n}\end{array}\right]$

In this matrix, $a_{m n}$ means the volume of allocated water into sector " $m$ " at the $n^{\text {th }}$ time step. Similarly, we can develop P and $P^{T}$ for price or direct benefit matrix; here, $p_{m n}$ is the direct economic benefit produced in sector " $m$ " by getting a unique volume of water at $n^{\text {th }}$ time step

$$
\begin{aligned}
& P=\left[\begin{array}{ccc}
p_{11} & \cdots & p_{1 n} \\
\vdots & \ddots & \vdots \\
p_{m 1} & \cdots & p_{m n}
\end{array}\right] \stackrel{\text { Transposition }}{\longrightarrow} \\
& P^{T}=\left[\begin{array}{ccc}
p_{11} & \cdots & p_{m 1} \\
\vdots & \ddots & \vdots \\
p_{1 n} & \cdots & p_{m n}
\end{array}\right] .
\end{aligned}
$$

We can define Eco, as a diagonal matrix, which calculated by summing up all economic benefits for each sector during the whole period. We also defined TEco index which resembles total economic benefit of each water allocation strategy for the whole period. Eco and TEco are described here: 


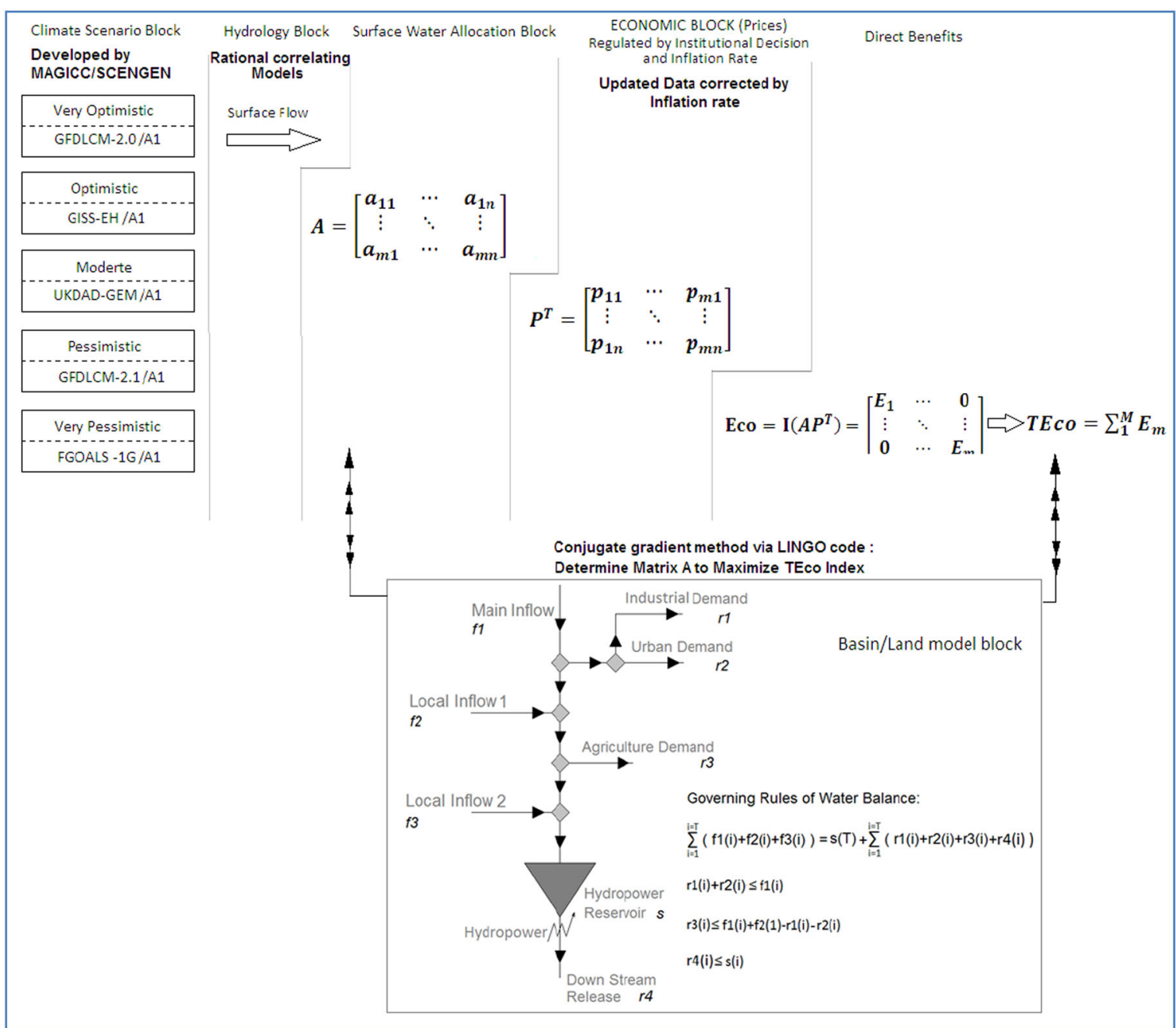

Fig. 2 Hydroeconomic model developed for the Rudbar Lorestan basin, including climate, hydrology, policy (allocation), economic, and land blocks. The basin/land block illustrates the schematic model of a single reservoir, including local inflows and demand points, the

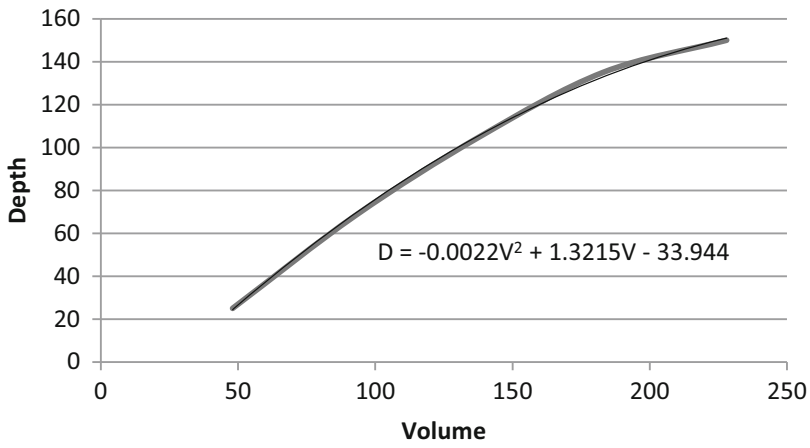

Fig. 3 Depth-volume curve and the correlated function of Rudbar Lorestan reservoir. The " $D$ " prompts absolute depth of reservoir in meter, and the " $V$ " is the total volume of reservoir, including dead volume in million cubic meters governing rules (water balance equations) are shown here. This model is used for the case study of the paper (Rudbar Lorestan hydropower dam)

$$
\begin{aligned}
\operatorname{Eco}= & I\left(\mathrm{AP}^{T}\right) \\
= & {\left[\begin{array}{ccc}
1 & \cdots & 0 \\
\vdots & \ddots & \vdots \\
0 & \cdots & 1
\end{array}\right] } \\
& \left.\times\left[\begin{array}{ccc}
a_{11} & \cdots & a_{1 n} \\
\vdots & \ddots & \vdots \\
a_{m 1} & \cdots & a_{m n}
\end{array}\right] \times\left[\begin{array}{ccc}
p_{11} & \cdots & p_{m 1} \\
\vdots & \ddots & \vdots \\
p_{1 n} & \cdots & p_{m n}
\end{array}\right]\right] \\
= & {\left[\begin{array}{ccc}
E_{1} & \cdots & 0 \\
\vdots & \ddots & \vdots \\
0 & \cdots & E_{m}
\end{array}\right] } \\
\text { TEco }= & \sum_{1}^{M} E_{m}
\end{aligned}
$$


Fig. 4 Total incoming (Direct benefits/TEco in the matrix definition) of Rudbar Lorestan basin in billion US\$ for the 2014-2050 duration. The horizontal axis shows the minimum downstream allocation from the deviation point of water transfer link into Qom (Ghom) city. GFDLCM $G C M$ indicates the most optimistic forecast, while the FGOALS GCM resembles the worst condition

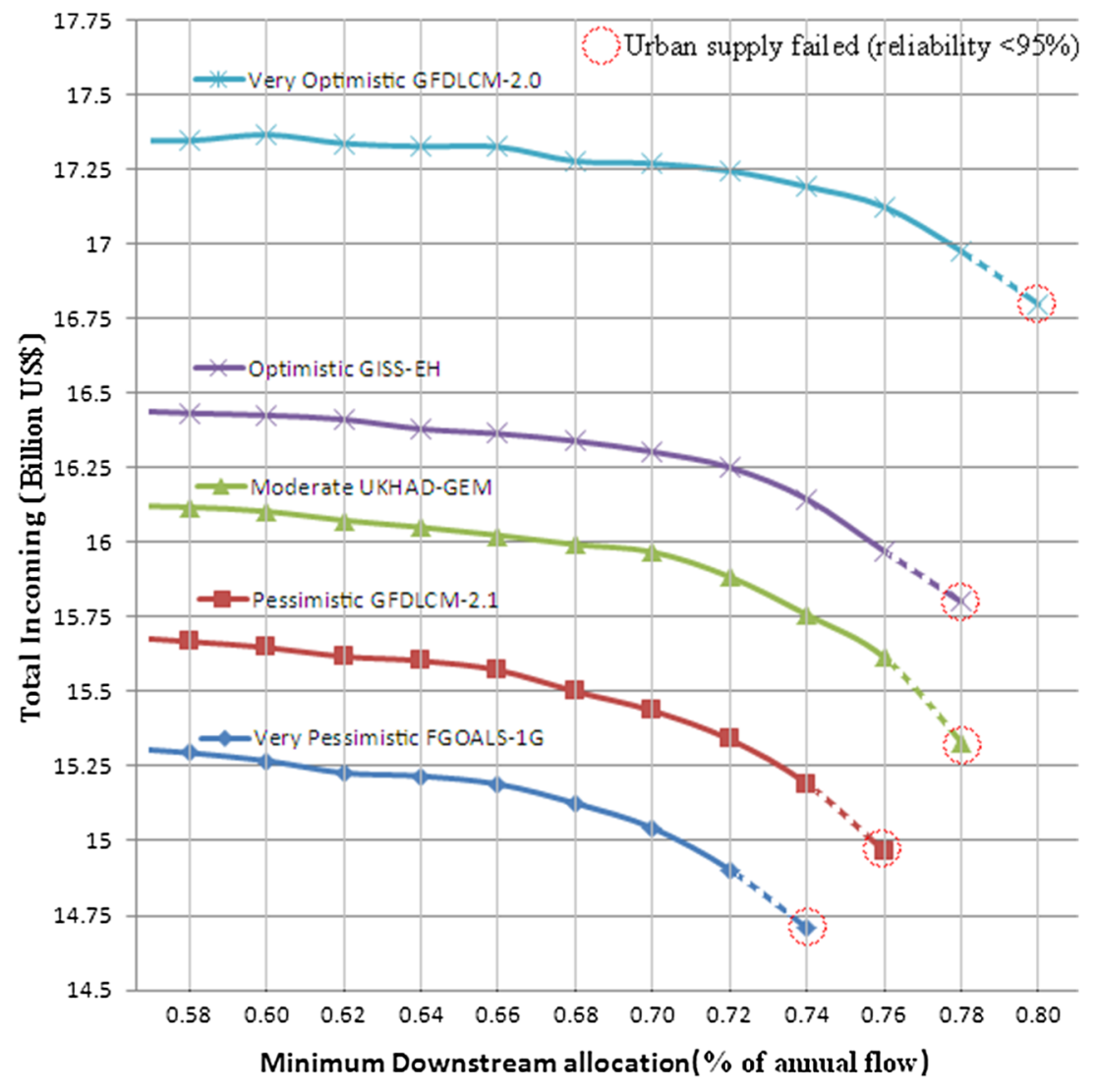

(wheat)/m3 (water) in 2005. However, there are reports, indicating that the real wheat productivity is around $0.55 \mathrm{~kg}$ (wheat)/m3 (water) in the traditional farming systems (Keshavarz et al. 2005). Furthermore, similar figures have been reported, showing wheat CWP from 0.5 to $1.63 \mathrm{~kg} / \mathrm{m} 3$ in Iran (Muthuwatta et al. 2013). In this paper, we assumed CWP of $1 \mathrm{~kg}$ (Wheat) $/ \mathrm{m} 3$ (Water) to model economic benefits of water allocated to agriculture sector in Iran. In addition, information in the United States Department of Agriculture (USDA) data base estimates the international price of wheat at 317 US\$/ton. Therefore, we can consider the gross economic benefit of $0.317 \mathrm{US} \$ / \mathrm{m} 3$ (Water) for water allocated to the agriculture sector. However, this figure does not contain social benefits, such as job opportunities.

In terms of urban water supply, it is difficult to obtain a reliable price estimate without subsides. However, we used research done in the adjacent providence (Kohkeloye and Boyerahmad) with very similarities in infrastructures and consuming culture that estimated the economic value of drinking water as 6877 Rials (0.275 US\$) per cubic meter (Tahami Pour and Kavoosi Kalashami 2012).

Determining the true price of electrical energy in Iran is also not simple. Where the previous pattern has focused on variable price depending on the weather condition, the government has decided to make a uniform charge table for 
Fig. 5 Total hydropower production in GWh Scale for 2014-2050 duration against minimum downstream allocation. The maximum coefficient of annual production/theoretical capacity is limited to $35 \%$

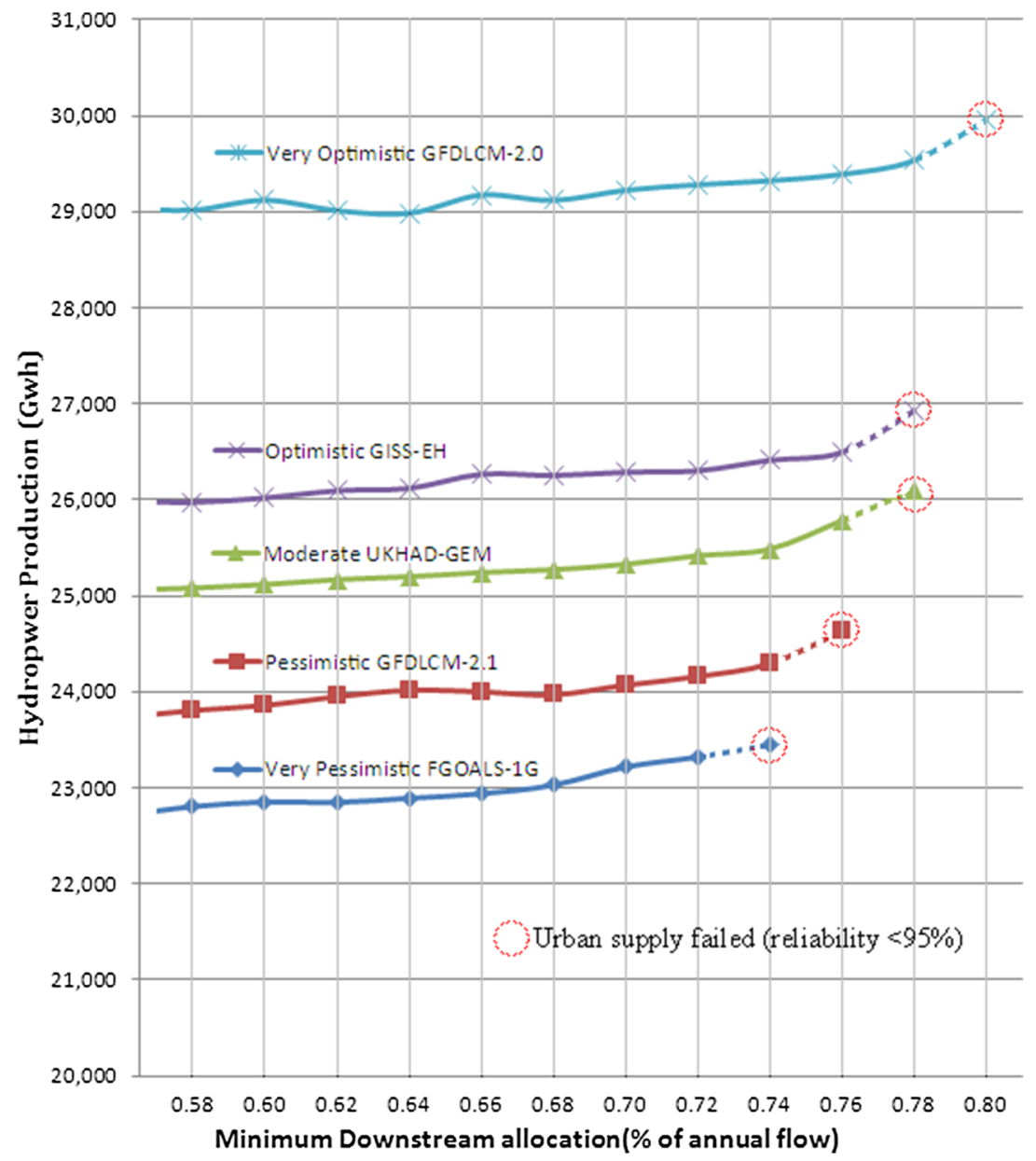

Results

Figure 4 illustrates the total benefits of system under five GCM-scenario combinations and shows total direct benefits (incoming) of system against minimum downstream allocation (from deviation point). By rising downstream allocation, the total benefits of system will reduce. The worst condition happens for the very pessimistic FGOALS GCM with $74 \%$ downstream allocation when the TEco drops into less than 14.75 billion US $\$$ for the 37 years period. The best probable condition is for very optimistic GFDLCM GCM at the $50 \%$ downstream allocation by around 17.3 billion US\$ for the same duration. In addition to drop of the TEco, more downstream allocation is constrained by a policy imperative that is $95 \%$ reliability of urban water supply.

The considerable difference between hydroelectric price and urban water price might be a reason to interpret why more downstream allocation acts against TEco index. By reviewing the graph, this fact must be considered that all points of graph have been developed by an optimizer model that shows the best probable allocation pattern for an exclusive downstream allocation. However, the purpose of the model is to maximize TEco index, and the figures of hydropower production must 

benefits) for urban sector during 2014-2050 period against minimum downstream allocation
Fig. 6 Total incoming (direct
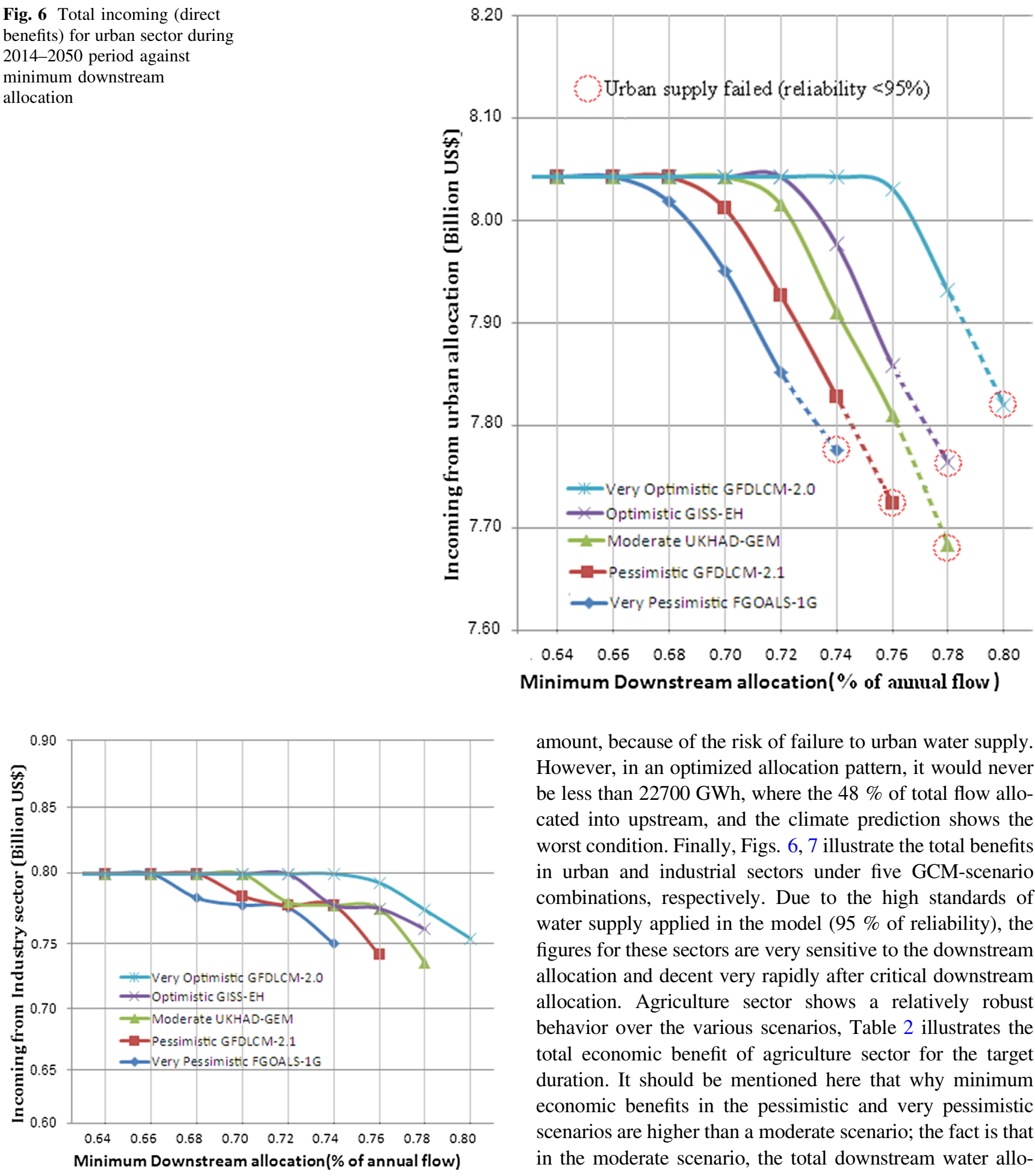

Fig. 7 Total incoming (direct benefits) for industrial sector during 2014-2050 period against minimum downstream allocation

be considered in the decision-making procedure. Figure 5 illustrates the projected hydropower production for the 37 years period (2014-2050) in the GWh scale. According to this graph, the maximum power production will limit in $30000 \mathrm{GWh}$ for the best condition and can never exceed this amount, because of the risk of failure to urban water supply. However, in an optimized allocation pattern, it would never be less than $22700 \mathrm{GWh}$, where the $48 \%$ of total flow allocated into upstream, and the climate prediction shows the worst condition. Finally, Figs. 6, 7 illustrate the total benefits in urban and industrial sectors under five GCM-scenario combinations, respectively. Due to the high standards of water supply applied in the model (95\% of reliability), the figures for these sectors are very sensitive to the downstream allocation and decent very rapidly after critical downstream allocation. Agriculture sector shows a relatively robust behavior over the various scenarios, Table 2 illustrates the total economic benefit of agriculture sector for the target duration. It should be mentioned here that why minimum economic benefits in the pessimistic and very pessimistic scenarios are higher than a moderate scenario; the fact is that in the moderate scenario, the total downstream water allocation could reach to $78 \%$ without disrupting upstream constrains; in contrast, this proportion is limited to 76 and $74 \%$ of total inflow for pessimistic and very pessimistic scenarios, respectively. However, as the Rudbar Lorestan basin is situated in a mountain range, the agriculture sector is relatively small and with very limit water demand. Therefore, it plays the minor role in water balance and is able to keep its productivity of the limited downstream allocation. 
Table 2 Total economic benefit of agriculture sector for 2014-2050

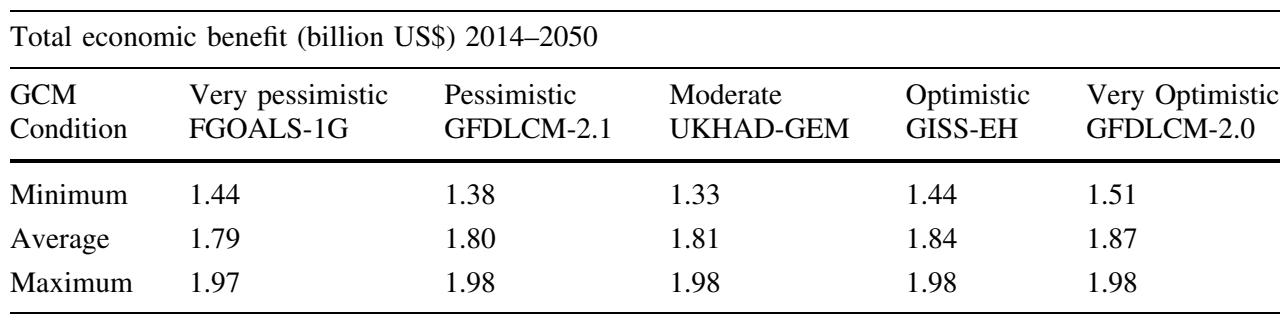

The figures are shown in billion US\$

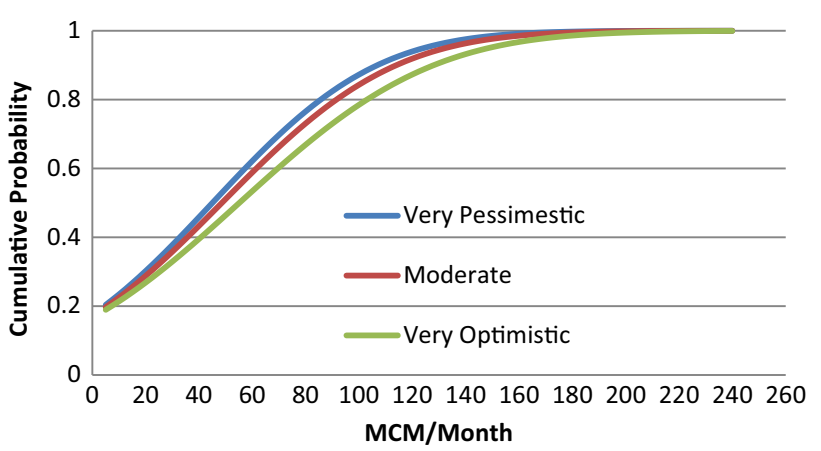

Fig. 8 Cumulative probability of downstream flow that can be considered for supplying the environmental demand in a fix $50 \%$ downstream allocation protocol

Although minimum environmental demand has not been considered as a direct restriction in the model, considering the flow regime of the river in the forecasted period, a minimum river flow of $15 \mathrm{MCM} / \mathrm{Month}$ by the reliably rate of $75 \%$ (for environmental proposes) has been secured in a fixed $50 \%$ downstream allocation protocol. This rate of flow will most probably occur during August. Figure 8 illustrates the cumulative probability curves for downstream flow for the moderate and extreme scenarios. The largest gap between very optimistic and very pessimistic scenarios happened in a flow around $80 \mathrm{MCM} / \mathrm{Month}$, where the reliability rate differs between 66 and $76 \%$. In addition to the secured downstream flow, other branches of Dez basin would supply the downstream flow before the next major reservoir (Dez Hydropower dam); however, this supply is not reliable in the long term. This is due to the fact that further water management programs on the upstream side of other branches are under study. There is also an under construction project to transfer water from the adjacent branch of this basin to Qom city for urban proposes. Nevertheless, there is no official plan for further water transfer plans in the upstream of the Rudbar Lorestan branch, at least during the next decade.

\section{Discussion}

While climate change may have considerable impacts over water resources systems and subsequently over the stakeholders, it is possible to reduce economic impacts via an optimized water allocation. In Rudbar Lorestan basin, the maximum rate of flow decent is evaluated to be around $30 \%$ for A1 scenario under FGOALS-1G GCM. The results of the optimized allocation show that the agriculture sector is able to save its economic efficiency without any considerable decent in the economic index. In the general scope, a comparison between GISS-EH and FGOALS-1G revealed that the total economic benefits of basin for a $50 \%$ fix downstream allocation are 16.4 and 15.35 billion US \$, respectively. These figures show a $5 \%$ drop of economic efficiency, while the difference between predicted flows of these two scenarios is more than $20 \%$. Loss of urban water is the most critical constraint which limits hydropower production under 30000 GWh for the 37 years period which means that the power plant will be operational with $20 \%$ annual efficiency, while the designed annual efficiency is $35 \%$. Subsequently, a review of the trends indicates that in this model, the main trade-off is between Urban and Hydropower, and agriculture and industrial sectors play only minor roles. Similar condition is also visible amongst other reservoirs in Iran with big group of urban water consumers in arid and semi-arid regions (Alizadeh and Keshavarz 2005; Abrishamchi and Tajrishi 2005).The significant gap in the prices of hydroelectric and urban water is the main reason that explains why a greater the downstream allocation reduces the TEco index. Owing to this fact, urban demand is going to be the major factor in water allocation not only because of the volume but also for the reliability standards which trends to keep the future storage via restriction of hydropower production. Next step, after this paper, would be using of true value of water instead of the direct benefit; therefore, it is our pleasure to announce that a research work has been initiated to apply true value of water as the economic indicator via socio-economic review.

Acknowledgments Special thanks go to Mr. Alireza Daemi Deputy of Planning and Economic Affairs, Iran Ministry of Energy, for her cooperation to provide local data and raw hydrologic materials.

\section{Appendix 1}

The hydrologic base of model is constructed on the base of a forecasted flow series from historical data and applied effects of GCMs outputs in the regional scale. MAGICC/ 


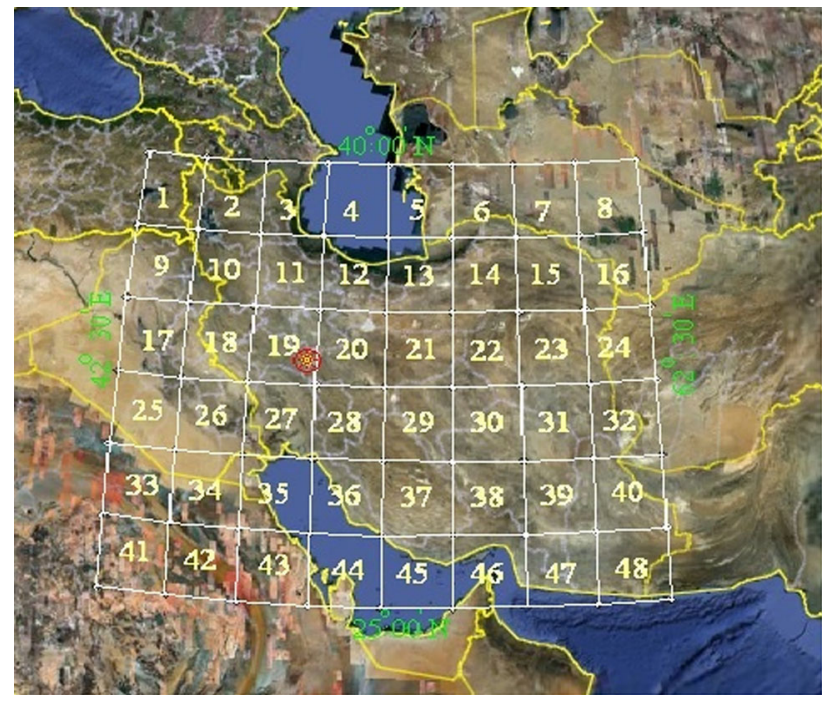

Fig. $92.5 \times 2.5$ degrees resolution of MAGICC/SCENGEN over Iran, the location of the basin is displayed in the eastern border of Cell No. 19

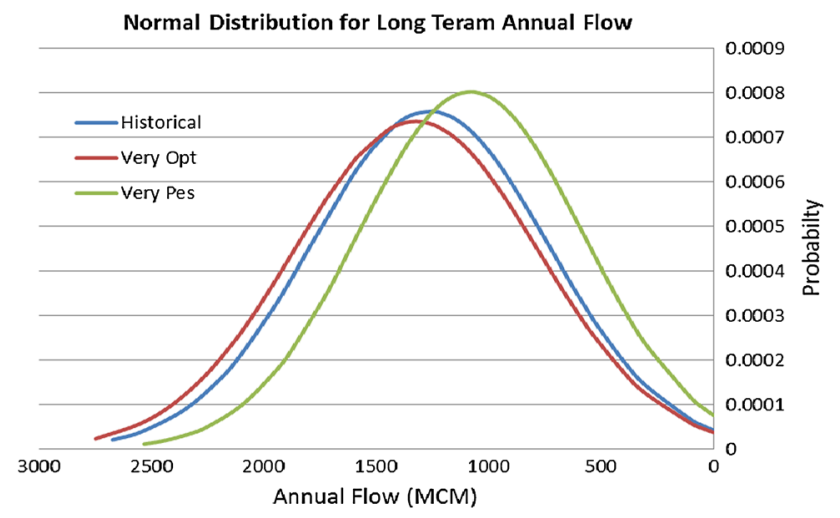

Fig. 10 Normal distribution of flow in MCM scale for three scenarios of historical (without climate change effect), very optimistic, and very pessimistic
Table 3 Hydrologic assumption applied in the reservoir model

\begin{tabular}{ll}
\hline $\begin{array}{l}\text { Maximum reservoir capacity of Rudbar } \\
\text { Lorestan Dam }\end{array}$ & $200 \mathrm{MCM}$ \\
\hline $\begin{array}{l}\text { Minimum operational Capacity of } \\
\text { Rudbar Lorestan Dam }\end{array}$ & $48 \mathrm{MCM}$ \\
Initial storage of the Reservoir & $114 \mathrm{MCM}$ \\
Depth-volume curve & $\mathrm{D}=-0.0022\left(\mathrm{~V}^{\wedge} 2\right)+$ \\
& $1.3215 \mathrm{~V}-33.944$ \\
Turbine efficiency & $95 \%$ \\
Maximum annual busy rate & $35 \%$ \\
Power plant capacity & $450 \mathrm{MW}$ \\
Max downstream transfer rate & $59.6 \mathrm{MCM} / \mathrm{month}$ \\
\hline
\end{tabular}

SCENGEN (version 5.3) has been used to forecast precipitation changes in a regional scale. The outputs are gridded to $2.5 \times 2.5$ degrees latitude/longitude network which is shown in Fig. 9. To downscale results, a $0.5 \times 0.5$ degrees subnetwork developed in the cells No. 19 and No. 20 calculated results by the reverse-distance method. Using a rational rainfall-runoff model, the forecasted flow pattern is calculated till 2015. The normal distribution for annual flow in MCM (Million Cubic Meters) scale for the three conditions is illustrated in Fig. 10. The modeled region includes two hydrometric stations (Qalyan and the Construction site stations) and two synoptic stations (Qalyan Sakaneh and Kakolestan Synoptic stations); in addition, the data of two adjacent synoptic stations (Buin va Miandasht and Aligudarz) have been applied to fill some gaps of the historical data. The stations and their geographic position are shown in Fig. 11.

In addition, a LINGO base optimization code is used with a combination of hydrological (Table 3) and economic assumption (Table 4, "Appendix 2") to find the most optimum allocation scenario.
Fig. 11 Geographical position of hydrometric and synoptic station in Rudbar Lorestan basin

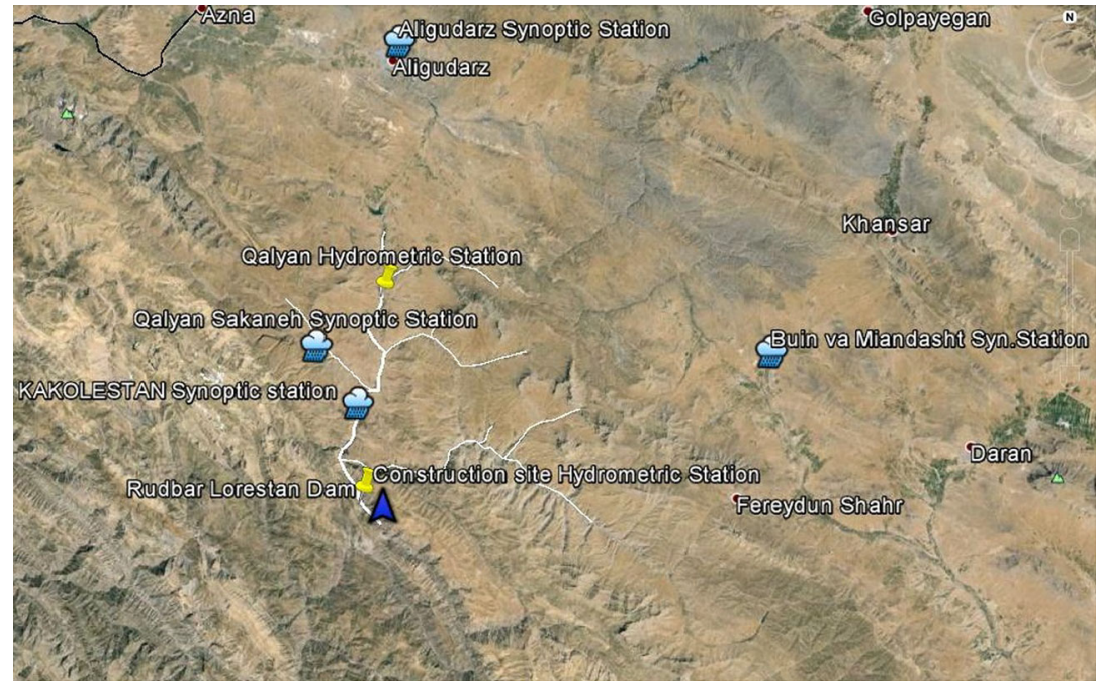




\section{Appendix 2}

\section{See Table 4}

Table 4 Economic assumptions applied in the LINGO optimization code

\begin{tabular}{|c|c|c|}
\hline Assumption & Reference & Model Input \\
\hline $\begin{array}{l}\text { Price of water in } \\
\text { urban sector is } \\
0.275 \text { US\$ per } \\
\text { cubic meter }\end{array}$ & $\begin{array}{l}\text { Tahami Pour and } \\
\text { Kavoosi Kalashami } \\
\text { (2012) }\end{array}$ & $\begin{array}{l}\text { Government Gross } \\
\text { Benefit of } 1 \text { cubic } \\
\text { meter of water in } \\
\text { urban } \\
\text { sector }=0.275 \\
\text { US\$ }\end{array}$ \\
\hline $\begin{array}{l}\text { Crop water } \\
\text { productivity (CWP) } \\
\text { for wheat is } 0.5 \text { to } \\
1.63 \mathrm{~kg} / \text { cubic } \\
\text { meter }\end{array}$ & $\begin{array}{l}\text { Muthuwatta et al. } \\
\text { (2013) }\end{array}$ & \multirow{3}{*}{$\begin{array}{l}\text { Government Gross } \\
\text { Benefit of } 1 \text { cubic } \\
\text { meter of water in } \\
\text { agriculture } \\
\text { sector }=0.317 \\
\text { US\$ }\end{array}$} \\
\hline $\begin{array}{l}\text { The applied value is } \\
1 \mathrm{~kg} / \text { cubic meter }\end{array}$ & & \\
\hline $\begin{array}{l}\text { International price of } \\
\text { wheat (average } \\
\text { 2012-2013) } 317 \\
\text { \$/ton }\end{array}$ & $\begin{array}{l}\text { United States } \\
\text { Department of } \\
\text { Agriculture } \\
\text { (USDA) }\end{array}$ & \\
\hline $\begin{array}{l}\text { Price of hydropower } \\
\text { electricity is } 0.017 \\
\text { US\$/Kwh }(2008)\end{array}$ & $\begin{array}{l}\text { Guillaume and Zytek } \\
\text { (2008) }\end{array}$ & $\begin{array}{l}\text { Government Gross } \\
\text { Benefit of } 1 \mathrm{kWh} \\
\text { of energy in } \\
\text { hydropower } \\
\text { sector }=0.017 \\
\text { US\$ }\end{array}$ \\
\hline $\begin{array}{l}\text { Price of water in } \\
\text { industrial sector is } \\
0.164 \text { US\$ per } \\
\text { cubic meter }\end{array}$ & $\begin{array}{l}\text { Portal of Iran } \\
\text { Ministry of Energy }\end{array}$ & $\begin{array}{l}\text { Government Gross } \\
\text { Benefit of } 1 \text { cubic } \\
\text { meter of water in } \\
\text { industrial } \\
\text { sector }=0.164 \\
\text { US\$ }\end{array}$ \\
\hline $\begin{array}{l}\text { Average of long-term } \\
\text { annual Inflation } \\
\text { rate for economic } \\
\text { benefits of water in } \\
\text { Agriculture } \\
\text { sector }=7 \%\end{array}$ & $\begin{array}{l}\text { Calculated by } \\
\text { subtracting inflation } \\
\text { rate of global price } \\
\text { from domestic } \\
\text { inflation rate }\end{array}$ & $\begin{array}{l}\text { Annual Inflation rate } \\
\text { for economic } \\
\text { benefits of water in } \\
\text { agriculture } \\
\text { sector }=7 \%\end{array}$ \\
\hline $\begin{array}{l}\text { Average of long-term } \\
\text { annual Inflation } \\
\text { rate for economic } \\
\text { benefits of water in } \\
\text { urban, hydropower, } \\
\text { and industrial } \\
\text { sectors }=8 \%\end{array}$ & $\begin{array}{l}\text { Calculated by } \\
\text { subtracting inflation } \\
\text { rate of global price } \\
\text { from domestic } \\
\text { inflation rate }\end{array}$ & $\begin{array}{l}\text { Annual Inflation rate } \\
\text { for economic } \\
\text { benefits of water in } \\
\text { urban, hydropower, } \\
\text { and industrial } \\
\text { sectors }=8 \%\end{array}$ \\
\hline
\end{tabular}

\section{References}

Abrishamchi A, Tajrishi M (2005) Interbasin water transfer in Iran. In: Water conservation, reuse, and recycling: proceeding of an Iranian American workshop p 252-271

Alaya AB, Souissi A, Tarhouni J, Ncib K (2003) Optimization of Nebhana reservoir water allocation by stochastic dynamic programming. Water Resour Manage 17(4):259-272
Alizadeh A, Keshavarz A (2005) Status of agricultural water use in Iran. In: Water Conservation, Reuse, and Recycling: Proceedings of an Iranian-American Workshop p 94-105

Andersson L, Wilk J, Todd MC, Hughes DA, Earle A, Kniveton D, Layberry R, Savenije HG (2006) Impact of climate change and development scenarios on flow patterns in the Okavango River. J Hydrol 331(1-2):43-57

Ansari V, Salami H, Veeman T (2014) Distributional consequences of subsidy removal from agricultural and food industry sectors in Iran: a price-based SAM analysis. J Agric Sci Technol 16(1):1-19

Arunkumar R, Jothiprakash V (2012) Optimal reservoir operation for hydropower generation using non-linear programming model. J Inst Eng (India) Series A 93(2):111-120

Brown S, Shrestha S, Riley SJ (1999) The allocation of resources to stormwater pollution control. IAHS PUBLICATION, Florida p 381-392

Chikamoto Y, Kimoto M, Ishii M, Mochizuki T, Sakamoto T, Tatebe H, Komuro Y, Watanabe M, No-zawa T, Shiogama H, Mori M, Yasunaka S, Imada Y (2013) An overview of decadal climate predictability in a multi-model ensemble by climate model MIROC. Climate Dyn 40(5-6):1201-1222

Demirel MC, Booij MJ, Hoekstra AY (2013) Effect of different uncertainty sources on the skill of 10 day ensemble low flow forecasts for two hydrological models. Water Resour Res 49(7):4035-4053

Exbrayat JF, Buytaert W, Timbe E, Windhorst D, Breuer L (2014) Addressing sources of uncertainty in runoff projections for a data scarce catchment in the Ecuadorian Andes. Climatic change 125(2):221-235

George B, Malano H, Davidson B, Hellegers P, Bharati L, Massuel S (2011) An integrated hydro-economic modelling framework to evaluate water allocation strategies I: Model development. Agric Water manag 98(5):733-746

Gleick PH (1987) The development and testing of a water balance model for climate impact assessment: modeling the Sacramento Basin. Water Resour Res 23(6):1049-1061

Graveline N, Majone B, Van Duinen R, Ansink E (2014) Hydroeconomic modeling of water scarcity under global change: an application to the Gállego river basin (Spain). Reg Environ Change 14(1):119-132

Guillaume D, Zytek R (2008) Islamic Republic of Iran: Selected Issues (EPub), International Monetary Fund publication, ISBN 1452714142, 9781452714141

Heinz I, Pulido-Velazquez M, Lund JR, Andreu J (2007) Hydroeconomic modeling in river basin management: implications and applications for the European water framework directive. Water Resour Manag 21(7):1103-1125

Jaghdani TJ, Brümmer B, Barkmann J (2012) Comparison of methods for the valuation of irrigation water: case study from Qazvin, Iran. Irrig Drain 61(3):375-385

Jiang T, Chen YD, Xu CY, Chen X, Chen X, Singh VP (2007) Comparison of hydrological impacts of climate change simulated by six hydrological models in the Dongjiang Basin, South China. J Hydrol 336(3):316-333

Jin X, Xu CY, Zhang Q, Singh VP (2010) Parameter and modeling uncertainty simulated by GLUE and a formal Bayesian method for a conceptual hydrological model. J Hydrol 383(3):147-155

Kalashami MK, Kalashami MK, Khiyavi PK, Alipour HR, Chabok RG, Eslami M (2014) Challenges and opportunities for improving irrigation water productivity in IRAN (case study: cultivation of rice at Guilan province)

Keshavarz A, Ashrafi S, Hydari N, Pouran M, Farzaneh EA (2005) Water allocation and pricing in agriculture of iran/water conservation, reuse, and recycling: proceedings of an Iranian- 
American Workshop/National Academies Press, 2005/ISBN 0309181194, 9780309181198

McKinney DC (1999) Modeling water resources management at the basin level: review and future directions, vol 6. IWMI, Colombo, Sri Lanka. ISBN 92-9090-376-7

Messner F, Zwirner O, Karkuschke M (2006) Participation in multicriteria decision support for the resolution of a water allocation problem in the Spree River basin. Land Use Policy 23(1):63-75

Muthuwatta LP, Rientjes THM, Bos MG (2013) Strategies to increase wheat production in the water scarce Karkheh River Basin, Iran. Agric Water Manag 124:1-10

Najafi MR, Moradkhani H, Jung IW (2011) Assessing the uncertainties of hydrologic model selection in climate change impact studies. Hydrol Process 25(18):2814-2826

Perry CJ (2001) Charging for irrigation water: the issues and options, with a case study from Iran. International Water Management Institute, Colombo, Sri Lanka, Research Report 52, ISBN 9290904275, 9789290904274

Pour MT, Kalashami MK (2012) Applying CVM for economic valuation of drinking water in Iran. Int J Agric Manag Dev 2(3):209-214

Rosegrant MW, Ringler C, McKinney DC, Cai X, Keller A, Donoso $\mathrm{G}$ (2000) Integrated economic-hydrologic water modeling at the basin scale: the Maipo River basin. Agric Econ 24(1):33-46

Safa HH, Morid S, Moghaddasi M (2012) Incorporating economy and long-term inflow forecasting uncertainty into decision-making for agricultural water allocation during droughts. Water Resour Manag 26(8):2267-2281

Schlüter M, Savitsky AG, McKinney DC, Lieth H (2005) Optimizing long-term water allocation in the Amudarya River delta: a water management model for ecological impact assessment. Environ Model Softw 20(5):529-545

Serrat-Capdevila A, Valdésa JB, Péreze JG, Baird K, Mafa J, Maddock T (2007) Modeling climate change impacts and uncertainty on the hydrology of a riparian system:88 The San Pedro Basin (Arizona/Sonora). J Hydrol 347(1-2):48-66

Singh A, Panda SN (2013) Optimization and simulation modelling for managing the problems of water resources. Water Resour Manag 27(9):3421-3431

Tahami Pour M, Kavoosi Kalashami M (2012) Applying CVM for economic valuation of drinking water in Iran. Int J Agric Manag Dev (IJAMAD) 2(3):209-214

Takama N, Kuriyama T, Shiroko K, Umeda T (1980) Optimal water allocation in a petroleum refinery. Comput Chem Eng 4(4):251-258

Turner RK (2004) Economic valuation of water resources in agriculture: From the sectoral to a functional perspective of natural resource management (Kerry Turner, Stavros Georgiou, Rebecca Clark, Roy Brouwer, and Jacob Burke) (Vol. 27). Food \& Agriculture Organization. Publishing Management Service Information Division, Rome, Italy, ISBN 92-5-105190-9 ISSN 1020-1203

Van Oldenborgh GJ, Doblas-Reyes FJ, Wouters B, Hazeleger W (2012) Skill in the trend and internal vari-ability in a multimodel decadal prediction ensemble. Climate Dyn 7(3): 1263-1280 4

World Watch Institute Data Base, WWI, annual report (2011-2012). http://www.worldwatch.org

Portal of Iran Ministry of Energy, http://www.moe.gov.ir. Accessed 22 Feb 2015

United States Department of Agriculture (USDA) Economic Research Service. http://www.ers.usda.gov/data-products/wheat-data.aspx. Accessed 26 Dec 2014

Young RA, Loomis JB (2014) Determing the economic value of water: concepts and methods. Routledge. HWA text and data management, London, ISBN 978-0-415-83846-7 